\title{
FOEHN WINDS AT WONSAN IN KOREA.
}

BY

T. OKADA.

A glance at the map of Korea shows that the general feature of the peninsular empire is very mountaineous. In the north there is a prominent range known as the Long White mountain. A range running southwards from this mountain divides the country into two parts, and forms the back bone of the empire. The axial range outshoots scveral lateral spurs, and subdivides the land into innumerable valleys and slops.

Korea is, on the other hand, frequently visited by barometric depressions and continental cyclones, especially in cold seasons. And it is not unfrequent that local secondary depressions develop in the neighbouring seas and inland of the empire. Thus it may be reasonably expected that there are many opportunities for the occurrence of foehn winds in Korea.

Unfortunately, however, as there was not a net of meteorological stations which can properly be so called, this interesting phenomenon has remained almost unnoticed. But foehn in Korea seems sometimes to develop in such a striking degree as it can not fail to attract attention of casual observer. La 
Pèrouse, the celebrated French navigator, gives us an account of a remarkable foehn with which he happened to encounter near the southeast coast of the Korean peninsula between the midnight of the 26 th and sunrise of the 27 th of May, 1787 . There is given below a passage of his vivid description of it from the "Voyage of La Pèrouse," which was quoted already by Prof. C. Abbe* in the Weather review of 1898 :-

"This day, May 26, was one of the finest and most interesting of our expedition, as we were enabled to take the bearings of more than thirty leagues of coast. Notwithstanding this fine weather the barometer fell to twenty-seven inches ten lines, but as its indications had been erroneous several times we continued our course till midnight along the coast, which we could discern by the light of the moon. The wind then chopped about from the south to the north with considerable violence, without the change being announced by any cloud. The sky was clear and serene, but it grew very black and I was obliged to stand off the shore, that I might not be embayed by the easterly winds. If the clouds did not give us warning of this change we had an indication of it which we did not understand, and which it is not, perhaps, easy to explain. The men at the masthead cried out that they felt burning vapours, resembling those of the mouth of an oven, coming in puffs every half minutes. All the officers went to the masthead and felt the same heat. The thermometer at that time was at $14^{\circ}$ upon deck. We sent one up to the cross trees, and it rose to $20^{\circ}$. These puffs of heat, however, passed

\footnotetext{
* Notes from the Voyage of La Pèrouse. M. W. R. Oct. I898. p. 624.
} 
with great rapidity, and in the intervals the temperature of the air did not differ from that of the temperature of the level of the sea. During the night we experienced a gale of wind from the north which continued only seven or eight hours but the sea ran very high." .

Early in 1904, the Japanese government established meteorological stations of the first order at Fusan, Moukpo, Chemulpo, Wonsan, Yongampo, Chennampo and Joshin. Daily observations made at these stations are telegraphically communicated to the Central Meteorological Observatory at Tokio. In my practice of charting these observations, I observed the fact that a singularly great rise of air temperature which could not be accounted for as the result of simple heating due to insolation, often took place at Wonsan. Closely examing the journal of observations I found that the abrupt rise of temperature is almost always associated with winds coming from northwest to southwest. In fact, Wonsan is frequently visited by $W$-foehns of very intence nature.

A description of the topography of Wonsan will perhaps make the matter clearer. Wonsan lies on the eastern coast of North Korea, and its geographical coordinates are $127^{\circ} 26^{\prime} \mathrm{E}$ and $39^{\circ} 9^{\prime} \mathrm{N}$. It is surrounded by high mountain ranges, except on the east side. In the north, a spur of the famous Long White mountain (Paik-san) is lying while in the south Mun-san forms a natural barrier. In the west there is a long range of the high mountains which are a part of the axial range of the peninsula. The range is of a uniform height of about I 500 metres, and its prominent peaks are so few that as Tu-nu-san and Koang-Syön-Kokai are only to be mentioned.

Now a few typical foehns that have ever occured at Wonsan are given below:- 


\section{$-4=$}

Foehn of the 27th April 1905.-Clear and rather calm weather prevailed in North Korea on the morning of the 27th. The air was very damp, and the relative humidity was $95 \%$ in general. The air temperature at Wonsan was comparatively lower than that at Yongampo and Chemulpo, the difference. being $3^{\circ}$. But with the commensement of westerly wind, the air temperature rapidly rose at Wonsan, and reached $24.2^{\circ}$ within a few hours. The relative humidity at Wonsan sank from $96 \%$ at $6 \mathrm{a} . \mathrm{m}$. to $24 \%$ at $2 \mathrm{p} . \mathrm{m}$. The weather chart of $2 \mathrm{p}$. m. shows that a shallow barometric depression which came from south of Chang: tung was lying over the gulf of Korea while an area of high barometer was covering North China and Liaotung. A northerly gale was prevailing on the coast of Liaotung and a westerly strong wind in North Korea.

The table given below contains the result of observations at the three stations in North Korea. Wonsan lies on the east side of the central mountain range of North Korea while Yongampo and Chemulpo are situated on the west sicle. A careful comparison of the observations made at Wonsan with those at the other two places will clearly show that the abnormal rise of temperature at Wonsan was caused by the westerly downward current from the mountain range.

\begin{tabular}{|c|c|c|c|c|c|c|c|c|c|c|}
\hline \multirow[b]{2}{*}{ Time } & \multicolumn{2}{|c|}{ Temperature.' } & \multicolumn{3}{|c|}{ Relative humidity } & \multicolumn{3}{|c|}{ Wind. } & \multicolumn{2}{|c|}{ Cloud. } \\
\hline & $622 \mathrm{p}$ & IOP $\max$. & $6 a$ & $2 p$ & Iop. & $6 a$ & $2 p$ & Iop. & $\overbrace{6 \mathrm{a} 2 \mathrm{p}}$ & $\overline{\text { rop. }}$ \\
\hline Wonsan. & 4.622 .4 & 8.224 .2 & 96 & 24 & $9 \pi$ & $\mathrm{SW}(\mathrm{I.4}) \mathrm{W}$ & $W(6.5)$ & $\operatorname{SSE}(0.6)$ & o 8 & 0 \\
\hline Yongampo. & 6.013 .9 & 9.5 & 93 & $3 \mathrm{r}$ & $5^{s}$ & $\operatorname{ESE}(0.7)$ & $\operatorname{NNE}(7 \cdot 4)$ & $\mathrm{N}(4 \cdot 3)$ & o 10 & I \\
\hline Chemulpo. & $7.8 \times 2.7$ & 11.4 & 94 & 50 & 44 & $\mathrm{SW}(2 \cdot 3)$ & $\operatorname{IVSW}(6.8)$ & $\mathrm{N}(8.7)$ & Io 10 & I \\
\hline
\end{tabular}

An extract from the record of observations on the 27 th made atthe Wonsan meteorological stations is given in the following table:- 
IVONSAN. APRII 26 19C5.

\begin{tabular}{|c|c|c|c|c|c|c|}
\hline Time & $2 a$ & $6 a$ & IOa & $2 p$ & $6 p$ & rop \\
\hline Barometer & 761.5 & 761.4 & 760.3 & $759 \cdot 3$ & 760.6 & 764.3 \\
\hline Temperature & $5 \cdot 3$ & 4.6 & I 8.2 & 22.4 & I8.8 & 8.2 \\
\hline Relative humidity & 97 & 96 & 36 & 24 & 28 & $9 \mathbf{I}$ \\
\hline Wind direction & W & SW & W & $\mathrm{W}$ & SW & SSE \\
\hline Wind velocity & I.I & $x \cdot 4$ & 5.6 & 6.5 & 5.2 & 0.6 \\
\hline Cloudiness & o & o & Io & 8 & Io & 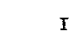 \\
\hline Clond forms & SK & SK & $\mathrm{CS}, \mathrm{C}$ & $\mathrm{CS}, \mathrm{C}$ & $\mathrm{SC}$ & $\mathrm{S}$ \\
\hline
\end{tabular}

Foehn of the 26th June 1904.- On this day the state of weather was very favorable for the occurrence of a foehn. A barometric depression $(755 \mathrm{num})$ was lying in the south of Vladiostok while an area of high barometer $(760 \mathrm{~mm})$ was covering North Clina and Shangtung. South-westly to westerly winds of light or moderate in force were prevailing on the coast of the peninsula. At Wonsan southwesterly wind set in on the early morning of the day, and gradually changed into west wind of increasing intensity. With occurrence of west wind the temperature rose in a striking degree and the humidity sank very low. The temperature was $19^{\circ} .7$ at $6 \mathrm{a} . \mathrm{m}$. and $31^{\circ} .7$ at $10 \mathrm{a} . \mathrm{m}$., and rose to $37^{\circ} .8$ at $6 \mathrm{p} . \mathrm{m}$. The maximum temperature recorded was $38^{\circ} .2$, We give below the result of observations taken at the Wonsan meteorological station:-

WONSAN. JUNE 261904 .

\begin{tabular}{|c|c|c|c|c|c|c|}
\hline Time & $2 a$ & $6 a$ & roa & $2 \mathrm{p}$ & $6 \mathrm{p}$ & rop \\
\hline Barometer & 755.6 & 755.5 & 756.1 & 755.6 & $755 \cdot \mathrm{I}$ & 759.4 \\
\hline Temperature & 20.3 & 19.7 & 31.7 & 36.8 & 37.3 & 22.2 \\
\hline Relative humidity & $7^{6}$ & $7 \mathrm{~S}$ & 30 & 27 & 25 & 75 \\
\hline Wind direction & $E$ & SW & WSW & WSW & W & W \\
\hline Wind velocity & 0.7 & 2.0 & 5.1 & 4.7 & 5.0 & \\
\hline Cloudiness & 4 & o. & 2 & Io & 3 & I \\
\hline Cloud forms & $\mathrm{Cs}$ & $\mathrm{CS}$ & C & $\mathrm{SC}$ & $\mathrm{SC}, \mathrm{K}$ & $\mathrm{CS}$ \\
\hline
\end{tabular}


- As in the preceding example, the observations made at Yongampo and Chemulpo together with those at Wonsan are given in the following table:-

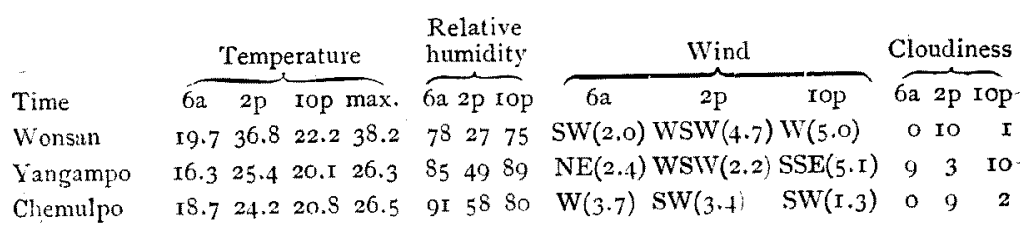

From this table it may be seen that the rise of temperature at Wonsan is much greater than that at the other two stations. The maximum temperature recorded at Wonsan is about $12^{\circ}$ higher than that at Chemulpo and Yangampo. The relative humidity observed at $2 \mathrm{p}$. $\mathrm{m}$. was about half that at the other two places. The two foregoing examples will be sufficient to show how foehn wind at Wonsan develops sometimes in such a remarkable degree as to cause an astonishingly high temperature and excessive dryness of air.

In order to give a further evidence for the occurrence of foehn at Wonsan I have picked up from the observations made at the station for 1905 and 1906 the hours of observation at which the relative humidity sank below $30 \%$, and have obtained the following result :--

Ifos Jan. Feb. March April May June July Aug. Sept. Oct. Nor. Des. Year

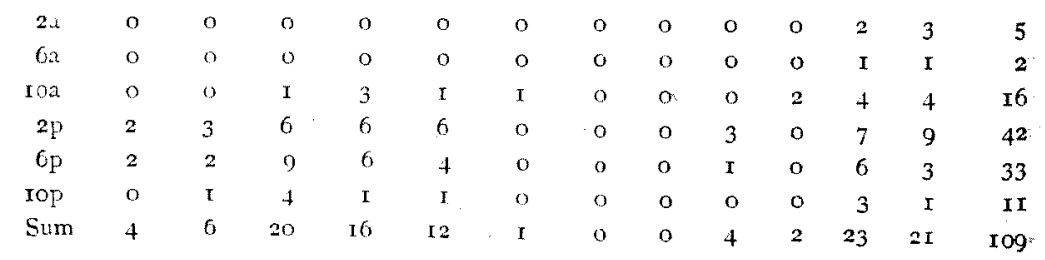




\section{$-7-$}

1906 Jan. Feb. March April May June July Aug. Sept. Oct. Nov. Dec. Year

\begin{tabular}{|c|c|c|c|c|c|c|c|c|c|c|c|c|c|}
\hline $2 a$ & 0 & 0 & 2 & 0 & I & o & o & 0 & 0 & 0 & 2 & I & 6 \\
\hline $6 a$ & 0 & 0 & 2 & 2 & 2 & $\mathbf{I}$ & 0 & 0 & 0 & $o$ & 2 & 0 & 9 \\
\hline Ioa & $\mathbf{I}$ & o & 4 & 9 & 0 & $o$ & o & 0 & 0 & $o$ & 4 & I & 19. \\
\hline $2 \mathrm{p}$ & 6 & 2 & 7 & Io & 6 & $\mathbf{I}$ & o & 0 & I & 4 & 8 & I & 46 \\
\hline $6 \mathrm{p}$ & 2 & o & 8 & 8 & 4 & o & o & o & 0 & 0 & 3 & 0 & 25 \\
\hline rop & o & 0 & 2 & 2 & o & $o$ & 0 & 0 & 0 & 0 & 3 & 3 & 10 \\
\hline Sum & 9 & 2 & 25 & $3 \mathbf{r}$ & 13 & 2 & 0 & 0 & I & 24 & 22 & 6 & 115 \\
\hline
\end{tabular}

Thus the hours of observation (termin) in which the humidity falls below $30 \%$ occurs most frequently early in spring and late in fall. It is most frequent from noon to evening, and very rare in the morning. The number was 108 in all in 1905 and I 5 in 1906 , and is about 5 per cent of the total mumber of "termins".

Distributing the number of "termins" with humidity below $30 \%$ according to the direction of wind we have the following result:-

\begin{tabular}{|c|c|c|c|c|c|c|c|}
\hline \multirow[b]{2}{*}{ Direction } & \multicolumn{3}{|c|}{1905} & \multicolumn{4}{|c|}{ I9०6 } \\
\hline & Termin & Total & $\%$ & $\overparen{\text { Termin }}$ & Total & & $\%$ \\
\hline $\mathrm{N}$ & I & I 28 & 0.5 & 2 & 117 & & 1.7 \\
\hline NNE & 0 & 45 & o & 0 & 36. & & o \\
\hline $\mathrm{NE}$ & 0 & 297 & 0 & 0 & 153 & & o \\
\hline ENE & o & 30 & o & 0 & 80 & & 0 \\
\hline $\mathbf{E}$ & $I$ & $I_{57}$ & 0.6 & 0 & $\mathrm{~T} 92$ & 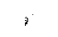 & 0 \\
\hline ESE & 0 & $2 \mathrm{~T}$ & 0 & $I$ & 17 & & 5.9 \\
\hline $\mathrm{SE}$ & I & 58 & I. 7 & 0 & 50 & & o \\
\hline SSE & $I$. & 24 & 4.2 & o & 33 & & o \\
\hline $\mathrm{s}$ & 2 & 75 & 2.7 & 3 & 147 & & 2.7 \\
\hline SSW & 0 & $5 I$ & o & 2 & 67 & & 3.0 \\
\hline SW & $x 6$ & $43^{8}$ & 3.6 & 19 & 282 & & 6.7 \\
\hline WSW & $I_{5}$ & 119 & I 2.6 & I6 & 129 & & I 2.4 \\
\hline W & 50 & 436 & II. I & $5 \mathrm{I}$ & $45 \mathrm{I}$ & & II. 3 \\
\hline WNW & ro & 76 & 13.1 & 7 & 73 & & 9.6 \\
\hline NW & Io & I03 & 9.7 & 13. & $x 76$ & & $7 \cdot 4$ \\
\hline NNW & I & 34 & 2.9 & I & 69 & & I.t \\
\hline Calm & o & $9^{8}$ & 0 & o & II 8 & & o \\
\hline
\end{tabular}


The "termin" with such a degree of dryness of air occured mostly with southwestly to northwesterly wind; IOI out of 224 cases, i. e. 45 percent occurred with west wind. Even if we take into account that the dryness occurs most frequently in winter during which the direction of prevailing wind is north to west, we find, by comparing the percentages given in the above table, that dryness of air is mostly associated by westerly wind coming down from the high mountain range.

In concluding this short note, it may be permitted to add that the secondary barometric depression which is caused by foehn sometimes develops near Wonsan and Joshin in North Korea. The depression of this kind which was already investigated by Dr. Billwiller and others also frequently develops in central and southeastern Japan, especially near Kofu, Nagano and Mayebashi, and causes thunderstorms in summer and squall in winter over Southeastern Japan.

I hope to publish a fuller account of the depression in a future number of this journal.

March 2I Igo7. Tokio, 